\title{
GOD AS FATHER: THE MALENESS OF GOD
}

\author{
D.T. Williams
}

Department of Systematic Theology

University of Fort Hare

\begin{abstract}
It is fashionable today to try to avoid sexist language in theology, despite the Bible's consistent use of the masculine pronoun when referring to God. Although such an attempt has largely been engendered by modem culture, the maleness of God is not simply a hangover from a patriarchal society, but reflects a fundamental maleness in God's dealing with man. It emphasises the idea of redemption by grace alone over against creation, and such aspects as the adoption of Christians as sons. The maleness of Christ likewise has not simply been cultural, but is significant theologically. This is not to deny any femininity in God, but to assent that male features predominate. Such an idea does not reduce the status of women, but rather an emphasis on redemption raises it. Raising the starus of women in society would in fact reduce the pressure to demasculinize God.
\end{abstract}

\section{INTRODUCTION}

The Anglican Church is currently in a state of controversy, as they have been for quite a time, over the question of the ordination of women. The arguments and implications are well known, such as the effect that such ordination would have on relations with the Roman Catholic Church. Typically it is argued that priests are male in so far as they stand in the place of Christ and the Father, and a woman "clearly" cannot do that (Packer, 1977:80). On the other hand, it is frequently asserted that as God himself cannot be either male or female, so likewise a priest or minister can be of either sex. The question must, however, be put as to whether this assertion of the non-maleness of God is in fact justified.

The non-sexual nature of God is virtually axiomatic in modern theology. To quote popular author, Richard Foster,

\begin{abstract}
I should at the outset note the special problem of the personal pronoun when referring to God. I think it is obvious to all that God is not a male deity as opposed to a female deity. God is beyond and includes our distinctions of sexuality. As long ago as the 14th century, Juliana of Norwich declared, "As truly as God is our Father, so truly is God our Mother" (Foster, 1987:ix).
\end{abstract}

Foster is apologizing for sexist language, which in modern theological writing is forbidden, believing, however, that a correct usage is "semantically awkward and 
aesthetically abhorrent" as well as failing to express God's greatness. Quere (1985:13) here makes an interesting suggestion. As language pertaining to God must be in a unique sense, a return to capitalizing the pronoun, would both remind the reader of this and be grammatically satisfactory. The maleness of God is, however, as is now fashionable, denied.

Such a denial has two roots. Firstly it is felt that as God does not reproduce as we do, He cannot exhibit sexuality. However, as will become clear, sexuality involves more than the ability to reproduce, and some of these aspects are indeed characteristic of God. Secondly, it is felt that ascribing maleness to God was due to the superiority of the male in pre-modern and especially Biblical culture. As modern culture is more enlightened about recognising the equality of the sexes, so the maleness of God is an anachronism which should be disposed of. It will be seen, however, that the Biblical maleness of God had a deeper root than culture, and moreover, that the equality of the sexes is not so much hindered by the maleness of God as supported by it.

\subsection{Biblical culture}

In Biblical times, so it is asserted, there was no questioning of the supremacy of the male. Probably going back to primitive times when sheer strength was vital, the male was dominant, and so society was patriarchal. An alternative modern explanation is basically similar, but sees the origin of the maleness of the deity in a Freudian analysis (e.g. Hamerton-Kelly, 1979). ${ }^{1}$ It would have been unthinkable therefore to refer to God as female. Kings and priests were also male.

However, Biblical culture, and particularly Old Testament culture, was not so monolithically male-dominated (cf. also Hamerton-Kelly, 1979:7). Even in the monarchy, the queen mother had power, and occasionally absolute power, although only when there was no king. The culture was not rigidly male, yet God is consistently referred to as male.

Rather, the maleness of God is emphasized in Israel not because of a cultural pattern, but as a contrast to the surrounding theologies (cf. Bloesch, 1985:39). Israel, after occupying Canaan, was always under threat from the local gods and had to assert distinctiveness. Emphatically, a major aspect of the local religion involved sexuality, which could be perceived as a threat to a very different concept of God. On the one

\footnotetext{
1 I tend not to find explanation here for the existence of matriarchal societies, which are by no means that rare.
} 
hand, the Baalim were male, with the concurrent ideas of power, victory in war and so on, but they are always seen in conjunction with the Astaroth, the females, and it is the union of the two, guaranteeing fertility of women, animals and the land, which is fundamental to Canaanite religion, and utterly rejected by Israel.

The point at issue was, and is, fundamental. In Canaanite theology, the action of God is directly linked to the prosperity of the land and animals, and God can be made to act by means of human action. The emphasis is upon biological existence and procreation and so emphasizes the female. The function of the worshipper is likened to the then current concept of the male. In a way often enacted in cultic prostitution, he plants a seed, but the mother enables it to grow. ${ }^{2}$ In contrast to Baalism, Israelite theology rather stressed the sovereignty of God. God provides fertility and prosperity, but cannot in any sense be forced to do so. Israel emphasized God's transcendence and so denied a direct association with fertility (Hayter, 1987:14). He chose and redeemed Israel, but this was not due to anything that they had done.

It was not because you were more in number ... that the LORD chose you ... but it is hecause

the LORD loves you ... (Deuteronomy 7:7-8)

Thus while Baalism emphasized creation (or rather procreation), Israel, while still portraying God as Creator, rather sees God as a sovereign redeemer, entering into special relationship beyond biological existence. Perhaps that can be illustrated by the fourth commandment, which stresses the sovereignty of God in the injunction to keep the Sabbath. In Exodus, it is because of creation, as in six days God created and rested on the seventh, but in the later Deuteronomic recension, the reason given is the redemption in the Exodus, and the link with the seven days of the Passover feast. Thus, while both religions are bisexual, the Canaanite is predominantly female, while the Israelite is predominantly male. The other pole is not denied, just as a human person is really bisexual, with both male and female characteristics (e.g. Winter, 1986:145, or Edwards, 1981:32). What matters is what is dominant. It will be seen that a redemptive religion presupposes a male deity, whereas a religion emphasizing existence and procreation is likely to see God as female.

Feminist writers, then, see New Testament practice as conditioned by the maledominated Jewish and Greek cultures. However, the Jesus who had such a concern for

\footnotetext{
2 In passing, it is noteworthy that such a concept, far from heightening the importance of the female, serves to diminish it. Woman becomes a garden, or a mere womb nurturing the seed of the male, which alone has life.
} 
women, so out of keeping with his culture, categorically gave God an unequivocable male title. It is particularly significant that Jesus nearly always addressed God as "Father", as there was little real precedent for this (Hamerton-Kelly, 1979:20, 53f), but cf. Moltmann-Wendel (1986:100), who asserts that Jesus' use of "Abba" cannot be understood patriarchally. Despite going against so much that was dear to his fellow Jews, there is no hint that he ever questioned reference to God as male.

\subsection{Modern society}

It is no accident that a society which is moving away from Christianity and its doctrine and values also stresses the female, because the female is particularly linked to existence and procreation. Modern culture finds its philosophical base in creation, or rather, in existence. An "enlightenment" philosophy sees men and women as equal as human beings, thus simply on the basis of their existence. In so doing, it causes an emphasis on the individual rather than the community. For this reason a woman tends to become discontented about being supported by her husband (relying on his "grace"), and wants her own income as an individual on the same basis as a man. Inequality in the work sphere was a prime driving force for the feminist movement (e.g. MoltmannWendel, 1986:13f). However, such a philosophy, which minimizes sexual differences and the complementary roles of the sexes, is ultimately in danger of degrading women. Because of the fact of childbirth and the consequent traditional role of the mother to care for her children, she tends to interrupt any career and become less advanced in it. It is only the rare woman who overcomes this, or even wants to. Moreover, of course, the woman is constantly hampered in her competition with men purely because of differences in strength and physical make-up.

The Christian Church, on the other hand, with stress upon redemption ${ }^{3}$ rather than on existence, has had the effect of raising women to equality with men, because both men and women were redeemed in exactly the same way, through the redemption purchased by the death of Christ and through their adoption as sons and daughters of God. Hence Paul can assert equality (Galatians 3:28), but still acknowledge the distinctive role of the sexes. It was the Christian religion, with stress on redemption, which raised the status of woman in the ancient world.

\footnotetext{
${ }^{3}$ This is not the place to consider whether redemption is limited to some or given to all. The whole idea of redemption is downplayed by modern man in any case. The prevalent notion is of universalism. Simply because a person exists, he has a right to eternal life (if such a notion is believed at all). The idea that there is any discrimination, so that some are redeemed while others are not, is abhorrent to a modern "enlightenment" man. In contrast, Christianity has traditionally seen salvation as a gift, but not extended to all. The most consistent view of this is, I believe, that of conditional immortality, where the unregenerate do not continue to live.
} 


\section{REDEMPTION AND THE MALENESS OF GOD}

It is not my purpose to argue that the essence of Christianity is redemption. This is my presupposition. Rather it is to argue that given such a supposition, the maleness of the Father follows. This is not, however, to say that the idea of creation relates to the female only. Edwards (1981:27), in a spirited defence of the feminine in God, asserts that creatio ex nihilo in fact emphasizes the maleness of God. I do not feel that her argument is persuasive, but it is a possibility. I am not therefore arguing for God's maleness because the Bible says so, although I do believe that this is a valid and weighty point which cannot simply be disregarded. However, the maleness of the Father is fundamental to the idea of redemption, because redemption involves the idea of adoption, and the relation of adoption, although not exclusive to a father, is characteristic of his role. The relationship between Israel and God is not primarily one of procreation but of election and adoption as sons (Hamerton-Kelly, 1979:31). The few Old Testament references to God as Father are more likely to refer to adoption than to begetting (Hayter, 1987:26). Paul argues (Romans 8:14f, Galatians 4:5) that a Christian is such because he has been adopted as a son, not simply because he exists; my argument is that this means God is Father, and only secondarily Mother.

An illustration should help. A woman conceives and carries a child, finally giving birth to it. She is in no doubt that the child is hers, even in modern practice where a newborn baby is often whisked away and only later returned to the mother. There is a bond, an identification, a full knowledge of intimate relationship. But what of the male? He did have something to do with the origin of the child, but a long time ago, and since then he has really had no role. He is now presented with a baby and is faced with a choice. Unlike the woman, he does not know for certain that the child is his. (This was particularly true before modern science, as in Biblical times.) He can only accept it on trust. In effect he has to adopt, to accept the baby as his, before life can proceed. He procreated, now he must adopt, and if the latter is not done, whether consciously or without thought, no full relationship can exist between him and the baby. Adoption and paternity are therefore connected, they are integral parts of each other. As Quere remarks, "the designation 'Father' in the Bible has more to do with God as Redeemer than God as Creator" (Quere, 1985:5). The relation of the mother, therefore, although she must also adopt in a sense, is mainly based on the procreative, that of the father, although he also procreates, is based on the redemptive or adoptive. The choice of the male is stressed as against the passive acceptance of the female. 
A second example, this time from the lips of Jesus. He told the story of the Prodigal Son (Luke 15:11f), where the son strained the relationship of procreation between himself and his father. On his return he was fully expecting to be rejected because of his action, or at best to be hired as a servant. The wonder of the story is that the father went beyond expectation, and adopted him again as son. It is this act of adoption which Jesus brought forward here as a characteristic of God as Father, a love receiving without necessary reason.

The necessarily different relationship that exists between a father and his son as compared to a mother and a son is further seen to be characteristic of God as a Father rather than as a Mother.

Firstly, as is seen in the parable of the Prodigal Son, the characteristic of a father is to give without being obliged to. Christian theology emphasizes this aspect of God: we are saved by grace, we cannot earn the favour of God, it is given as a gift (e.g. Ephesians 2:8,9). This aspect is more characteristic of a father rather than a mother. Initially of course, in the sexual act itself, despite the fact that both partners are giving of themselves to the other, and both are receiving, the heart of the matter is the gift of the semen by the male to the female. Moreover, the initiative basically lies with the male. At the extreme level, a man can force a woman to be pregnant, but a woman cannot force a man. Once conception has occured, moreover, a child will normally be born without any further conscious effort, indeed it is preventing this which is difficult. Her action is not one of grace but is forced.

Furthermore, once the child is born, it is the role of the mother to care for and nurture the child. It is argued nowadays that that could equally be the duty of the father, but the difference in relationship means that the mother is usually the one who does this. It is a rare mother who can trust the care of a child to another, but fathers do not have the same attitude. This means that the mother gives to the son, but under a real sense of obligation; the father also gives, but for him it is much more a matter of his own choice; without the same bond, it becomes a matter of grace.

Secondly, again due to the different relationship between the different parents and their son, discipline, at least in the final analysis, falls to the father. The mother can discipline, and usually does, but it is a rare mother who can really punish. A father, on the other hand, being less involved because of his adoptive relationship, can, and does, discipline. Such discipline is possible both because there is a relationship, but also because it is primarily adoptive rather than procreative (c.f. Hebrews 12:5f, where the writer stresses discipline as a characteristic of being a son). Hamerton-Kelly (1979:45) 
observes that every Old Testament reference to the fatherhood of God is in the context of discipline.

An incidental point, but not a minor one, is that a view of faith which tends to the sacramental emphasizes the feminine, so, for example, the Eucharist is viewed in a sense as feeding on God, as a mother suckles a child. However, a view which emphasizes grace would rather see the Lord's Supper as a remembrance and may then prefer to see God as male. It is significantly the "sacramental" churches which are most concerned with the ordination of women.

Related to this is that an emphasis on redemption must accompany a realisation of the distance between God and man, God's transcendence. If the need for such redemption is denied, there will be a tendency to replace God's transcendence by immanence, a move leading to pantheism (or panentheism), and ultimately to pagan witchcraft, which is indeed evidenced in some forms of feminism (c.f. Ruether, 1983b:64).

\subsection{Christ and the Father}

It may be objected at this point that the prime aspect of the Fatherhood of God is in relation to Christ rather than to men, and that this would appear to be more similar to creation than to redemption. ${ }^{4}$ Thus, even when Christ referred to his "Father", this would not be seen as implying maleness, but only the capacity to generate, so could mean both male and female or neither. As Moltmann (1983:53) says, God is a "motherly Father". The term father therefore, in respect of God would need to be desexualized, as indeed many are trying to do by the use of other terms.

However, such a line of thought makes the existence of the Christ independent of the incarnation and so devalues the human, resulting in Monophysitism. In a sense Jesus only commenced existence in Mary, and yet this does not deny a doctrine of preexistence even for humans (Hebrews 7:10), so how much more for the Son of God. Moreover, the relationship between Christ and the Father is not simply one of begetting or generation, but includes other aspects of paternity.

Firstly, the Bible records the earthly origin of Jesus by a virgin birth. The whole account is of course being questioned, for a number of reasons. However, I simply

\footnotetext{
4 Of course, the relation of God as Father to the Son is not creative or procreative but a different process known as begetting or generation. However, it is definitely not redemptive.
} 
want to show the implication of the story as it stands for the gender of God. It hardly needs to be said here that if the birth of Jesus involves one human parent, that one must be female, and therefore God is understood in the story as the male. To have a human father and divine mother is totally impossible, and the suggestion blasphemous (Bray, 1986:315), while with no father at all Jesus would not have been human. Bray adds that if Jesus had come from a heavenly mother's womb this would have implied inferiority, but more importantly, that such an origin would mean that Christians, as adopted children, could not possibly share the character and rights of the natural son. It is, incidentally, hardly possible to claim Mary as epitomizing the feminist vision as giving birth without male agency (as Sara Maitland, cited in Oddie [1984:85]). Maleness was involved, but not human maleness.

Secondly, a realization that a full paternal relationship involves more than simply a question of origins explains the vexed question of such texts as Acts 2:36 and Romans 1:4. Although some early thinkers believed that such texts proclaimed adoptionism, the granting of deity to a human Jesus, the Church rapidly condemned such teaching as heretical, as being inconsistent with the deity of Christ. However, what the texts refer to is not a bestowal of divinity as was suggested, but a recognition as such, just as a father needs to acknowledge paternity. The baptism of Jesus is then seen not as a bestowal of divinity in the shape of the dove, but as a recognition of divinity and an indication of the start of a new phase of life. Similarly the problem of when the calls of Jeremiah and Paul occurred may be answered in accordance with the same principle (Jeremiah 1:5, Galatians 1:15); what we have is a recognition of an existing state, but which needed acceptance by the called.

Thirdly, Christ probably had to be male, due to the culture into which he was incarnated; a woman would not have been able to do what he did. However, if Chris is in the image of the invisible God (Hebrews 1:3 etc.), and this is to be seen as nongendered or dual gendered because his Father is, this at least opens up the possibility of an accusation of Nestorianism and I believe Oxford-Carpenter (1984:11) could be accused of this. The divine Christ is divided from the human Jesus. Rather, a true incarnation means that the Son of God is just that, a Son, and so God the Father likewise must be in some respects male. Gerald Bray, (1987:27) interestingly turns this around, arguing that Jesus had to be male as the Father is male. Likewise, although it has been suggested that the Spirit is feminine, this is not likely. Suggestions for the femininity of the Spirit come from Dart or Moltmann (Quere, 1985:7) (cf. also Bloesch, 1985:6f). Bloesch (1985:33) points out that spirit in Hebrew, although grammatically feminine, takes a masculine adjective or pronoun, as can the otherwise neuter word in 
Greek. It is also incorrect to replace the Trinity of Father, Son and Spirit by "Creator, Redeemer, and Sustainer" as in some modern liturgies (Quere, 1985:10, Bloesch, 1985:47, 50f). Both suggestions divide the essence of the Godhead, either by different sexes, or by different functions. All three persons have the same essence, all three redeem, not only the Son.

Now it may be responded that the sex of a person does not belong to the real humanity of that person - otherwise, and this is a typical feminist argument, it would be impossible for a male Christ to save women. He could not substitute for them. Nevertheless, Christ stated that the sex of a person is irrelevant for salvation and does not affect the afterlife (Matthew 22:30). He does not, however, say that their sex is not recognisable and that they are completely androgynous, only that marriage becomes irrelevant in heaven. This is probably because in heaven there is full companionship with all, no exclusion from others being necessary (marriage is a "forsaking all others" in order to give full relationship to the one), and no need for procreation. In the afterlife the functions of marriage basically fall away. Sexuality, however, is so much part of a human personality that it must belong to the very innermost being of all. A person cannot lose it without losing a large part of what makes him a person. Ruether (1983a:12) notes the Gnostic myth of an original androgynous Adam, only divided into sexes at the Fall. Such an argument would make it possible for Christ also to be androgynous like the New Adam (Romans 5). However, Christ is surely understood to represent all the redeemed, male and female, even though he is male (Romans 5:12f), just as in the story of creation, Adam includes Eve.

Fourthly, the vitality and the closeness of human sexual relations are recognised by the image of Israel as the wife of God (e.g. Hosea) or in the New Testament, of the church as the bride of Christ. The picture is clearly of God and Christ as male, and never as female, even if that should be theoretically possible. The metaphor here, however, could be due to the cultural situation at the times when it was man who sought for and supported a wife.

In the light of this imagery, God is seen as father as related to mother, as well as related to son, and not just the latter, as would be more acceptable to feminists. This has a very practical implication for Christians as the Church, the Bride of Christ, for the production of children requires both a father and a mother. Thus for a person 10 become a Christian there is a necessity not only of an act of God, both creative and adoptive, but also the cooperative agency of the Church in witness. I do not believe that it is significant that if this metaphor were pressed home this makes Christians sons of Christ and so grandsons of the Father; a grandson can equally be termed a son. 


\subsection{Christ the Liberator}

Modern liberation theology sees Christianity in a socio-political light as justification for a struggle against the oppression of the poor. Using such Biblical material as the Exodus, Luke 4:18 and the message of the prophets, it sees God as being on the side of the poor and thus supporting a move which will benefit them. Feminist theology readily identifies with this, seeing women also as the oppressed, so poor women as doubly oppressed (Ruether, 1983a:137). Capitalism, the cause of much economic oppression, is also the cause of sexist oppression, at least in its basic ethos (Bruce \& Duffield, 1976:14)

The argument is often that just as Christ became incarnate in order to redeem those oppressed by sin, he also became poor to redeem the poor. Thus the necessity for identification became stressed in theology. This was supported by the missiological technique whereby the evangelist became as closely identified with the target culture as possible in order to preach to it (c.f. 2 Corinthians 9:20f). However, such identification, as well as being impossible in the full sense, may actually be counter-productive (just as evidence of a Christian culture and lifestyle may be an attraction to Christ). Likewise total identification with the poor means that one is as impotent as they often are to change their situation. Consequently it is also totally unnecessary for Christ to be identified as female in order to release the oppressed females. Representation and substitution need not imply identification.

In fact it was the unquestionably male Christ in the Early Church who achieved most for women's emancipation. Moreover, it is precisely what is implied by the fatherhood of God which spells liberation. On the one hand the relation of the adoption of Israel as God's son is connected with their liberation from Egypt, but on the other hand, a relationship, both Old and New Testament, based on grace, is liberating because it implies a free response and not a forced one.

\section{Superiority?}

It will be observed that my arguments for the maleness of the Father have not touched what is probably regarded as the key issue, that of the alleged superiority of men to women. It is believed that the Bible accepts the superiority of men due to the prevalent culture, and that this is simply transferred to the Godhead. For example Paul (the arch-chauvinist!) states that no woman is allowed to speak in the assembly (1 
Corinthians 14:34, 1 Timothy 2:11-12). The statements are possibly the opinion of Paul himself, but in the second case he does refer to the Genesis story of the creation and fall. He is not simply accepting a cultural practice. These stories, however, do not reveal inferiority; the creation of women merely reflects the need of men not to be alone, and the fall does not exactly show the ability of Adam to resist temptation. What is in view is not a hierarchical order but a difference in role.

Nevertheless the Bible would appear to endorse the practice of culture. Paul is quite explicit " ... the head of woman is her husband ... man was not made from woman ..." (1 Corinthians 11:3, 8), "Wives be subject to your husbands" (Ephesians 5:23) etc. However, Paul makes his remark in the context of a recognition of essential equality because of redemption, but also of a difference in role, as his explanation of 1 Corinthians 11:11 shows ("... in the Lord woman is not independent of man or man of woman ..." (my emphasis). Elsewhere he has to combat feelings of superiority in his illustration of the different roles of the parts of the body (1 Corinthians 12:14), and of course he is the author of the verse so loved by feminists "... there is neither male nor female, for you are all one in Christ Jesus" (Galatians 3:28). Again, this is in the context of redemption, but, in addition, the verse does not say that all are equal, but that all are one. A continued difference in role is recognised. Beckwith (cited in Oddie, 1984:58) points out that even the 1 Corinthians passage does not indicate women's inferiority, because as Christ's relation to the Father, and man's to Christ is not degrading, neither then is that of woman to man. Hayter (1987:120) points out that 1 Corinthians 11:3 uses the word "head" which implies "source" not "rank", whereas he could well have used kurios ("Lord"). Derivedness does not necessarily imply subordination.

As I have already stated, it was the Christian Church which elevated women in human culture and it is only in Christ that she will achieve a position of equality due to the recognition of equal redemption. It is significant that it is baptism, not circumcision, which is the rite of entry into the church. Outside the church, despite all the efforts of the feminists, I do not believe there will ever be real equality, simply because men and women are different. Some outstanding women will achieve, but basically inherent roles are dominant. Such inequality is only overcome by redemption.

It is not ascribing fatherhood to God which reinforces the dominance of the male, but because God is father, this should change our idea of fatherhood which could otherwise be oppressive due to inherited culture. The fatherhood of God combats sexism. To quote Hamerton-Kelly, 
God as Father: the maleness of God

Properly understood, therefore, the biblical symbol"Father" means virtually the opposite of what the radical feminists understand it to mean, freedom not bondage, responsibility not dependence, adulthood not infantilism (Hamerton-Kelly, 1979:121)

\subsection{Anthropomorphism}

The Biblical references to human features of God, such as hands, feet, face, etc. are rejected as literally true by most theologians. God is spirit, and therefore such references are inappropriate to God. Any idea of maleness would then likewise be rejected. A further, but related, feminist objection to the Fatherhood of God is that it is idolatrous in that it confers a human characteristic on God. Nevertheless, even if the crude idea of God actually having hands is to be rejected, yet the idea behind the anthropomorphism may not be. God acts, if not by hands as man does, but certainly effectively. Is not the point at issue that any anthropomorphism is dangerous not because of the language but because of the fear of limiting God to just that image? The fact that images of God were forbidden by the second commandment was because imaging God is a particular way, although not wrong in itself, was wrong if it excluded other images. The Bible, after all is full of imagery. God is an eagle (Exodus 19:4) but not just an eagle; he is a bull (Numbers 24:8) but more than that.

Our problem is that when we say man, we exclude woman and vice versa. Our definition is negative as well as positive, but this idea cannot apply to God. To say he is father is correct but this must not exclude all idea of the female. It is interesting to note that the most aggressive feminist movements actually find no place for men, whereas the more moderate either stress inherent equality or enhance femininity as being complementary to maleness. However, any term when applied to God must be clearly defined and will generally have a specific use. It must be obvious that referring to God as Father means that there are some similarities between God and a human parent, but also that such similarity is more characteristic of the male. However, there is no idea of either restricting God to this idea or divinizing human maleness (see Quere, 1985: 6f). I would, however, question his distinction between the name of God as male and the metaphorical reference to God as female.

\subsection{God as more than male}

It would seem that a Biblical religion is forced into a belief, in some sense, of the maleness of the Father. Therefore, feminist theologians are often driven outside the 
Bible to seek support for the idea of a non-male God. Ruether (1983a:21) cites Shakers (e.g. 1983a:133), Montanism (1983a:130), Gnosticism (1983a:127), etc. However, she believes that Biblical religion is irredeemably patriarchal, so that a resource for a feminine view of God can only be found outside the Bible (Ruether, 1983a:39). She explicitly draws on wider source material than the Biblical, and OxfordCarpenter (1984:13) also points out that goddess worship has an ancient but extraBiblical source. However, although Oxford-Carpenter admits that the major emphasis in the Bible is male, she believes that fruitful approaches (Oxford-Carpenter, 1984:24), which either stress the female as well as the male in God, or desex or depersonalize the Godhead, do have a Biblical warrant.

While acknowledging the dominance of the male image in the Bible, it must be noted that God sometimes expresses characteristics more typical of the feminine. Examples of this are Deuteronomy 32:18 and Isaiah 46:3, which use the image of giving birth, although only the former is realy explicit (but which of course could be interpreted in a non-maternal way). More frequent are pictures of the mother bird caring for the young (e.g. Psalm 17:8) and references such as Isaiah 66:13, which compare God to a mother without being as explicit as Deuteronomy 32:18.

Oxford-Carpenter (1984:17) also claims that parables such as that of the Prodigal son and the lost coin also show maternal characteristics. It is also likely that "compassion", such as in Psalm 51:1 and Isaiah 66:12, is connected to the Hebrew word for "womb" (c.f. Hayter, 1987:23). Such observations are valuable as they prevent denial of attributes such as compassion to God, which is clearly wrong. Nevertheless, it is clear that such references are very infrequent, not surprisingly in view of the Biblical rejection of fertility religion, and are also poetic, so they should not be taken too literally compared to ascriptions such as fatherhood to God which occur in a nonpoetic context.

Edwards (1981:27) believes that although the Bible clearly portrays God (symbolically) as male, God's femaleness comes through in such aspects as the Shekina, wisdom (sophia) or spirit (ruach) which are all grammatically feminine. This should not surprise us as they are all aspects of the way God relates to mankind, and relatedness is the basic feminist characteristic. It was probably only the fact that Christ was male, which meant the logos symbolism was preferred to the female sofia, even though both really refer to aspects of the same ("androgynous") reality. The identification of Christ with the feminine "wisdom" of the Old Testament has contributed to a recognition of the feminine in God, for example in Julian of Norwich. However, although she 
referred to Christ as "mother", she was careful to refer to the first person consistently as "Father" (Bloesch, 1985:47).

In any case, as modern studies on homosexuality have shown, sexual identity is not absolute. As Oxford-Carpenter (1984:9n) writes, "... I have awakened to my own androgyny". There is no such thing as an absolute male or female but all have the characteristics of both. Hayter (1987:38) helpfully points out that the only maternal and paternal functions which are not interchangeable belong to physical reproduction, but adds that these aspects are never predicated of God. Phipps (1975:515) interestingly claims that the Hebrew plural Elohim refers to both the male and the female in God, noting that it could be used of goddesses as well as God. Thus as it is argued (e.g. by Ruether, 1983a:36) that the creation narrative states that male and female equally are in God's image, which is the refore androgynous. Such an interpretaion, however, completely ignores Paul's comment in 1 Corinthians $11: 7$, where he specifically says that it was the man who was created in God's image. Nevertheless, that man at the same time included woman. Similarly, God, as male but including the female, created the man, including the woman.

In this case it is really irrelevant to try to demonstrate the feminine in God; what concerns us is that which is most characteristic which I believe, for God, is the male. What must not be done is to divide God into male and female, as the Greek dualist divided man into a spiritual mind (male?) and a passive inferior body (female?) or then dominance must occur.

\subsection{God as asexual}

A further approach is to see the male imagery as just that, imagery; a result of the necessity due to language of giving God some kind of sex. The Bible is, however, replete with images which are not sexual such as friend, liberator or teacher. Such are clearly personal, but are not at all conditioned by sexual connotations. Going yet further is to depersonalize God, noting pictures such as fire (e.g. Exodus 3, Hebrews 12:29, Acts 2). Barth's Revealer would come somewhere between the two.

These are valid pictures of God, but of course their existence does not lead to a denial of the validity of the descriptions which are more directly sexual. More particularly, as Foster (1987:91, and also Ruether, 1983a:36) argues, the creation of man as male and female in the image of God does mean that sexuality is part of God himself. Ruether (1983a:69) observes that God is not just a sexless abstract parent. Mary Daly, the 
"arch-feminist", correctly argues that personality must involve sexuality (which would then be male), hence, with her denial of the validity of the Biblical picture comes a denial of God's personality and even of his Being (Daly, 1973:33). God for her, as for Tillich, exists only in the sense of a verb, be-ing, and not as in any sense substantive. She epitomizes the logic of the position; God either does not exist, or exists, in some sense, as male.

Perhaps the main argument against the sexual nature of God is that it is meaningless as God does not procreate as we know it. Even in the story of the Virgin Birth, what actually happened must remain a mystery, as must the relationship between the preincarnate Christ and the incarnate Jesus. Nevertheless, even in human society, sexuality is expressed in many ways without the full intimate relationship leading to procreation. It is the confusion of these two, the relationship and the result of it, which has caused stress in the church from the Middle Ages to the Catholic Church of today, where frequently the sexual act was condemned if not used for procreation, leading to the debate over contraception. Rather, the sexual act is both for the purposes of expressing an intimate relationship and for procreation. It is for this reason that God is seen as sexual, for there is no deeper relationship possible between human beings than that expressed in the sexual act. As God's desire is to have a full relationship with man, this is frequently expressed in sexual metaphors. This is why the emphasis in theology must be on redemption, which involves an intimate personal relationship, rather than on procreation, which may be very impersonal.

It is significant that in his discussion of the meaning of the image of God, Hall (1986) believes that relationship is the key idea, and, as his subtitle shows, a relationship to the world as dominion over it. My belief is then that sexuality is not incidental to this, as Bird (1981) argues, but integrally linked to it.

\section{CONCLUSION}

Basically the objection to regarding God as male is a cultural matter. Because women are oppressed by men, it is an additional problem, as well as a ground for such oppression, to regard God as male. If, on the other hand, society did treat men and women as essentially equal, there would be no fundamental reason to object to regarding God as male (or female). Society after all recognises without any hint of superiority or inferiority a difference in roles, and so accepts a virtual restriction to one sex in some occupations. There are few infant school teachers who are male, and 
neither are many coal miners female, even though there are no restrictions. Society happily recognises a difference in role due to the different characteristics of the sexes, without an implied superiority. The same is true of God. Regarding him as male, as this better reflects the action of redemption, should in no wise render the female inferior in essence.

Nevertheless, a difference in role does tend to lead to views of rank, and thus is always a problem. For example, the simple reference to the Son of God naturally leads to a nuance of subordination in some cultures (it is always difficult to teach the Trinity in African culture; hence the popularity of the Jehova's Witnesses), even though theology happily recognises equality in essence as distinct from difference in relation. Such recognition needs to be expressed more clearly in society.

The issue for Christians is therefore not to argue for the femaleness or asexuality of God, but for the essential equality of men and women, without a confusion of roles as is the case in some manifestations of feminism. My contention is that it is precisely the Christian doctrine of redemption, so appropriate to the maleness of God, which gives women her dignity as equal to the male, as all are equally redeemed and equally valuable in the sight of God.

If this is the case, should not the church ordain women? I regret to confess that for me it is just not an issue, for I belong to a Christian tradition that has little problem with the ministry of women. Those of a more sacramental persuasion, who must see the minister as representing Christ, will no doubt continue to argue, but for those who emphasize rather the priesthood of all believers, and the mutual ministry of all to all can really dispense with a formal ministry in any case. Bruce and Duffield (1976:103), inter alia, quote Tillich to the effect that "there are in Protestantism only laymen ...". Those who minister are rather those who are called to do so, whether male or female, whose aim is to give Him all the glory.

\section{BIBLIOGRAPHY}

BIRD, P. 1981. Male and female He created them: (icn. 1:27b in the context of the Priestly account of creation. Hanvard Theological Review, 74(2):129-59.

BLOESCH, D.G. 1985. The Battle for the Trinity: the debate over inclusive God-language. Ann Arbor, Michigan : Servant (Vine).

BRAY, G. 1986. What will happen to God? (Pt. 1) Chunchman, 100(4):309-22.

BRAY, G. 1987. What will happen to God? (PL. 2) Churclman, 101(1):22-35.

BRUCE, M. \& DUFFIELD, G.E. eds. 1976. Why not? Priesthood and the Ministry of Women. 2nd ed. Abingdon Berks : Marcham Manor Press. 
DALY, M. 1973. Bcyond God the Father: Iowards a Philosophy of Women's Liberation. Bosion : Beacon.

EDWARDS, F. 1981. The Doctrine of God and the Feminine principle. Joumal of Theology for Southem Africa, 37:23-37.

FOSTER, RJ. 1987. Money Sex and Power: the Challenge of the Disciplined Life. Londen : Hodder \& Sioughion.

HALL, DJ. 1986. Imaging God. Dominion as Stewardship. Grand Rapids : Eerdmans / Now York: Friendship Press for Commission on Stewardship National Council of the Churches of Christ in Ihe USA.

HAMERTON-KELLY, R. 1979. God the Father: Theology and Patriarchy in the teaching of Jesus. Philadelphia : Fortress (Overtures to Biblical theology)

HAYTER, M. 1987. The New Eve in Christ: the use and abuse of the Bible in the debate about women in the Church. London : SPCK

METZ, J.B. \& SCHILLEBEECKZ, E. 1983. God as Father. Edinburgh : T \& T Clark / New York Seabury (Concilium 143)

MOLTMANN, J. 1983. The Motherly Father. Is Trinitarian Patripassianism replacing Theological Palriarchalism? (In Metz, J.B \& Schillenbecek\%, E. God as Father. Edinburgh : T \& T Clark / New York : Scabury (Concilium 143). p. 51-56.)

MOLTMANN-WENDEL, E. 1986. A land flowing with milk and honey; perspectives on feminist theology. London : SCM.

ODDIE, W. 1984. What will happen to God? Feminism and the Reconstruction of Christian Belief. London: SPCK.

OXFORD-CARPFNTER, R. 1984. Gender and the Trinity. Theology Today, 41(1):7-25

PACKER, J.I. 1976. Representative Pricsthond. Bruce \& Dufficld.

PHIPPS, W.E. 1979. The Sex of God. Joumal of Ecumenical Studies, 16 515-517.

OUERE, R. 1985. "Naming" God 'Father". Currents in Theology and Mission, 12(1):5-14.

RUETHER, R.R. 1983a. Sexism and God-talk; towards a feminist theology. Boston : Beacon.

RUETHER, R.R. 1983h. The female nalure of God: a problem in contemposary religious life. (In Metz, J.B. \& Schillebeckzz, E. Edinburgh : T \& T Clark / New York : Scabury (Concilium 143). (. . 61-68.)

WINTER, R. 1986. Homosexuality. (In Palmer, B Medicine and the Bible. Exeter Patcrnoster p 145-63.) 
